\title{
History and Use of Wood Pyrolysis Liquids as Biocide and Plant Protec- tion Product
}

\author{
Kari Tiilikkala*,1, Leena Fagernäs ${ }^{2}$ and Jasse Tiilikkala ${ }^{3}$ \\ ${ }^{I}$ MTT Agrifood Research Finland, Plant Production, FIN-31600 Jokioinen, Finland; ${ }^{2}$ VTT Technical Research Centre of \\ Finland, P.O. Box 1000, FI-02044 VTT, Finland; ${ }^{3}$ University of Turku, FI-20014 Turku, Finland
}

\begin{abstract}
Archeological studies have found that pyrolysis liquids were already used in the time of the Neanderthal. Wood vinegar and other slow pyrolysis liquids are produced as a by-product of charcoal production. However, future business ideas may be the other way round as pyrolysis liquids may replace synthetic chemicals in the form of pesticides and biocides.

Directives and regulations related to the sustainable use of pesticides govern and direct plant protection strategies towards a lower use of synthetic chemicals. It is hoped that many mega trends of global policies will boost the use of plant based products given that a reduced reliance on fossil fuel is a general target in the global food and feed production economy. Pyrolysis technology has been actively studied and developed around the world and is linked to the development of the knowledge based bio-economy. The importance and social impact of pyrolysis technologies will also be enhanced because it is a practicable technique in the sustainable use of wastes and biomasses. However, very little scientific evidence is available to support efficacy claims of wood vinegar and toxicology assessments of the products used. Wood tar has been investigated a bit more thoroughly. The aim of this review was to clarify the potential of slow pyrolysis liquids in agricultural use, in particular, in pesticide applications. In addition, some of the main challenges in developing novel bio control technologies are discussed and the barriers in the commercialization of biological control agents are revealed.
\end{abstract}

Keywords: Wood vinegar, pyroligneous acid, wood tar oil, essential oil, biorational, pesticide, biocide, wood preservative, slow pyrolysis, biochar, knowledge based bio-economy.

\section{BACKGROUND}

Globally changing pesticide policies and integrated pest management programs (IPM) aim to reduce pesticide risks on the environment and human health. It has been clearly stated that the hazards to health and the environment from the use of pesticides must be minimized and dependence on chemical control needs to be reduced. In Europe, a thematic strategy on the sustainable use of pesticides was adopted in 2006 by the European Commission [1] and as such, a new directive was put into force in 2009 [2]. Replacement of synthetic chemicals with "alternative plant protection techniques" has been mentioned in numerous policy documents related to the use of pesticides [3].

The highest demand on natural pesticides is in the organic farming where synthetic chemicals cannot be used for plant protection $[4,5]$. In Europe, replacement of chemicals with biological control agents has been slow but in Asia and the USA, botanical pesticides have already been placed on the market as green chemicals [6]. At the same time of increasing European environmental concern, the development of the Knowledge Based Bio-Economy (KBBE) concept clearly highlights that products of plant cells could replace

*Address correspondence to this author at the MTT Agrifood Research Finland, Plant Production, FIN-31600 Jokioinen, Finland;

Tel: +358400986172; Fax: +358341882584; E-mail: kari.tiilikkala@mtt.fi synthetic chemicals in the future and substantial research will be focused on bio-economy and the development of novel products [7].

One of the fast growing areas of bio-business is based on the use of pyrolysis technologies. Charcoal (biofuel and biochar) has been the main product of the conventional pyrolysis for a long time in most of the cases but recently byproducts of the process (green chemicals) have become more and more important. Locally produced wood vinegar has been used as a pesticide in countries where synthetic chemicals have not been available, or where the price of the chemicals has been too high for small scale farmers. Globally, the need to minimize the environmental risks resulting from pesticides leaching to ground water and waterways has bolstered the use of wood vinegar as a biocide and pesticide [8]. In spite of pesticide production, other factors, such as the production of green fuel from agricultural and forestry residues have enhanced the growth of pyrolysis bio-business to become an important part of KBBE and chemical production [9].

In many of the Asian countries, the tradition of utilizing botanicals has a long history [10] and a vision to develop biobased business strategies is one of the main streams of economic development $[11,12]$. Despite the long history of pyrolysis use, only a limited number of review articles focused on pyrolysis liquids as pesticides or biocides were found. In writing this review the most useful article found 
[13] gives an overview of wood vinegar used as a biocide and pesticide in agriculture, including plant production and protection as well as its role in animal husbandry. This conference paper as many other documents, include examples how to use wood vinegar but do not include scientific evidence to support all the examples.

Plant essential oils are more thoroughly studied as a pesticide than wood vinegar. Isman [14] provided a source of valuable information with regard to the use of essential oils as an insecticide, fungicide, repellent, nematicide and bioherbicide. Health and environmental impacts were tackled as well as commercialization of essential oil-based pesticides. The same author has also published a review article [15] which demonstrates the regulatory barriers of commercialization of bio-pesticides.

The aim of this paper was to clarify the potential of slow pyrolysis liquids in agricultural use, in particular, in pesticide applications. The first section describes shortly the history of pyrolysis and use of pyrolysis liquids and wood tar in the past. The second section focuses on the efficacy of pyrolysis liquids (wood vinegar) used in agriculture or as biocide. The last section is a vision related to KBBE, pyrolysis and use of wood vinegar in plant protection.

\section{TERMINOLOGY USED IN THIS REVIEW}

\section{Pyrolysis}

Pyrolysis is a thermal conversion process where the material is treated in an inert atmosphere in the absence of air or oxygen with final temperatures of about $500{ }^{\circ} \mathrm{C}$. The process yields solid char (charcoal, biochar), volatile condensable compounds (distillates) and non-condensable gases. Pyrolysis can be slow or fast depending on the process.

\section{Pyrolysis Oil}

Pyrolysis oil, also called bio-oil, is the liquid product from fast pyrolysis of biomass.

\section{Wood Vinegar, Pyroligneous Acid}

Pyroligneous acid, also called wood vinegar or mokusaku, is an aqueous liquid produced from slow pyrolysis of hardwood. The liquor is decanted from sedimentation tar.

\section{Tar}

Tar is dark, oily material produced by slow pyrolysis of wood, coal, or peat. The tar is separated from pyrolysis liquids by sedimentation.

\section{Pitch}

Tar can be fractionated into tar pitch and tar oils. Pitch is considered more solid than tar.

\section{Essential Oil}

Essential oils are produced from different plants by distillation, expression or solvent extraction. They are concentrated, hydrophobic liquids containing volatile aroma compounds from plants. Essential oils are also known as volatile or ethereal oils, or simply as the "oil of" the plant from which they were extracted, such as oil of clove.

\section{Biopesticide}

Certain types of pesticides derived from natural resources, such as animals, plants, bacteria, and certain minerals are referred to as biopesticides. For example, canola oil and baking soda can have pesticidal applications and may be considered as biopesticides. The term has been used also for a living organism applied as an inundative biological control agent or augmentative biological control agent.

\section{Biorational Pesticide}

A biorational pesticide is a chemical such as a toxin or growth regulator derived from a living organism and applied either as the entire dead organism or as an extract from the organism; or alternatively, the chemical or an analogue of it synthesized in vitro. The use of biorational pesticides has often been classed as chemical control rather than biological control as there is no single or legally clear, definition of the word biorationals. The Environmental Protection Agency (EPA) identifies biorational pesticides as inherently different from conventional pesticides, having a fundamentally different mode of action and consequently, lower risks of adverse effects from their use.

In the literature the terms of various pyrolysis liquids has been used vaguely and the international CAS (Chemical Abstracts Service) numbers do not give standard basis for differentiating wood vinegar or tar oils made of wood or other plant material. This kind of obscurity makes it difficult to compare results published by different authors.

\section{HISTORY OF PYROLYSIS LIQUIDS}

\subsection{Early History of Using Birch Bark Pitch}

History of using and producing birch tar dates back to the Middle Palaeolithic time of Neanderthal. The tar was manufactured by a thermal process, probably pyrolysis, from birch bark to yield pitch. Birch bark pitch was used as adhesive to haft tools and weapons. The earliest finds come from Germany and Italy and are estimated to be more than 80000 years old [16-18].

From Mesolithic (10000-5500 BC) and Neolithic (55002000 BC) dwelling sites in northern Europe, there is much evidence of birch bark pitch lumps with human teeth impressions. It is not clear if the pitch was used only for chewing purposes, or was it part of manufacturing and processing of pitch. There is ethnographical evidence that birch bark pitch was used for cleaning and refreshing teeth. It is possible that pitch was used for medical purposes and treating dental conditions $[19,20]$. Onwards from the Neolithic period, birch bark pitch was used as a universal adhesive and mastic. It was used for repairing, waterproofing and sealing ceramic vessels. Its usage and manufacturing was widespread in prehistoric and medieval times in Europe [21-23].

\subsection{History of Pyrolysis Techniques}

\subsubsection{Slow Pyrolysis Techniques}

In conventional pyrolysis processes, wood is slowly heated up to the maximum temperature. Lower process temperatures $\left(400^{\circ} \mathrm{C}\right)$ and longer vapour residence times favour the production of char. Besides slow pyrolysis, other terms 
such as carbonization, destructive distillation, and dry distillation are used for this kind of thermal process [24]. The pyrolysis of wood was probably human's first chemical process [25]. It is known to have been practiced by the ancient Chinese. The Egyptians, Greeks, and Romans made charcoal by wood carbonization, and collected the condensable volatiles for embalming purposes and for filling joints in wooden ships.

The most important product of carbonization is charcoal. Industrial carbonisation is carried out predominantly in large retorts with capacities up to $100 \mathrm{~m}^{3}$ of wood [26]. The average practical yields are about $35 \mathrm{wt} \%$ of wood, and depend on the wood species and wood size, carbonization system, processing time and final temperature. Beech wood is the dominant raw material for the production of charcoal in Europe. In addition, oak, ash, alder and maple are used. In North America, the raw materials include also hickory, elm, sycamore and some softwood species. In the Nordic countries minor amounts of birch is used, and in South America and South Africa, charcoal is produced mainly from hardwood species of Eucalyptus.

Until the late 1800's, wood carbonization was the major pyrolysis process, and supplied the increasing amounts of charcoal that were required for iron ore smelting [25]. The iron furnaces in the USA used charcoal exclusively until the 1840's, and somewhat later the share of the iron market produced with charcoal was increasingly replaced by that of coal and coke iron. By the 1900's, destructive distillation of wood was practiced widely on a commercial scale by heating wood in closed retorts. The vapours produced were condensed to give tar (wood tar or sedimentation tar) and an aqueous layer (pyroligneous acid). In the retorts about the same quantity of the major products charcoal and raw pyroligneous liquor (crude wood vinegar) are produced. This liquor is first settled and then decanted from the sedimentation tar. The tar can be fractionated into tar oils and tar pitch. Raw pyroligneous acid contains primarily methanol, acetic acid and soluble tar. By the turn of the century, wood was the only source for the latter chemicals.

The predominant use of wood as the principal raw material for the organic chemicals industry was short-lived [25]. Alternative processes for the production of acetone, acetic acid, and methanol were soon developed, and the petrochemical industry almost completely replaced the wood distillates market. Under present conditions, the production of these chemicals from wood distillates is rarely economically attractive in the Western Hemisphere. The rest of the world still uses wood carbonization to yield charcoal for heating, cooking, and industrial purposes, while chemicals are only occasionally produced as by-products.

Traditionally, charcoal was produced from wood using charcoal piles, earth kilns, or pit kilns [25, 27]. Hardwood was carefully stacked in a mound or pit around a central channel, and then covered with dirt, humus, moss, clay, or sod. The process was slow and it could take about 6 weeks before completion. Later, permanent kilns were introduced producing higher yields of charcoal. Brick or masonry was used to cover and contain the wood during carbonization, and doors were used for charging wood and removing product. Holes and chimneys were optimally located to regulate air flow and discharge flue gases. The retort furnaces were later developed to produce charcoal on a commercial scale and the recovery of by-products was possible. Different discontinuous and continuous systems are used. All commercial processes operate at near-atmospheric pressure.

\subsubsection{Destructive Distillation of Pine}

Destructive distillation of pine wood was once of great economic importance in the manufacture of naval stores [25]. Naval stores included turpentine, as well as pitch, tar, and resin, which were indispensable in shipyards for protecting surfaces and caulking seams of wooden ships. The destructive distillation process for pine was similar to that used for hardwoods, except that the products were charcoal, turpentine, pine oil, dipentene, pine tar, tar oils, and pitch. Charcoal was produced as a by-product residue. Softwood distillation gives lower yields of acetic acid and methanol than hardwood distillation [24], therefore longleaf and slash pine, especially in the form of recovered stumps, were favoured because of their high resin content.

\subsubsection{Fast Pyrolysis}

Since the oil price crisis in the early and late 1970's, considerable effort has been directed toward the development of processes for producing liquid fuels from biomass. Fast pyrolysis is one of the most viable methods for such conversion [28-31]. During fast pyrolysis, the biomass is rapidly (1000 ${ }^{\circ} \mathrm{C} / \mathrm{s}$ ) heated to about $500{ }^{\circ} \mathrm{C}$ during very short vapour residence time $(<2 s)$ and the vapours then rapidly cooled to give a dark brown fluid liquid called bio-oil, pyrolysis liquid or pyrolysis oil. A typical product distribution for dry barkfree wood is, on average, $64 \mathrm{wt} \%$ organics, $12 \mathrm{wt} \%$ pyrolysis water, $12 \mathrm{wt} \%$ char, and $12 \mathrm{wt} \%$ product gas.

\subsection{History of Wood Vinegar and Tar as Pesticide}

Use of plant derivatives in agriculture dates back at least two millennia in ancient China, Egypt, Greece and India. Wood vinegar also has a long history and it has been used daily, for example, in Japan as a result of numerous health claims related to the product. Since the 1930's, wood vinegar has also been used in agriculture as a fertilizer and growthpromoting agent [32]. Although the word ancient, related to the use of wood vinegar, has been mentioned in many documents and on web pages it was difficult to find good scientific evidence to attest the first records of wood vinegar used as pesticide. Probably only few documents are available or the information has been written in languages and in countries difficult to reach via modern information retrieval.

\section{EFFICACY AND USE OF WOOD VINEGAR IN AGRICULTURAL USE}

\subsection{Chemical Composition of Wood Vinegar}

The characterisation of liquid products from pyrolysis has been continued a long time. The products contain many organic components and the composition is very complicated. During the last twenty years the interest has mainly been focused on the liquid product from fast pyrolysis.

According to literature [24-26] the main organic components of wood vinegar are methanol and acetic acid. Other components are acetone, methyl acetone, acetaldehyde, allyl alcohol, furan and furfural, and formic, propionic and butyric 
acids. The settled tars can be fractionated into light and heavy oil fractions. The former consists of aldehydes, ketones, acids, and esters. Various phenols, including a high proportion of cresols and pitch, are present in the heavy oil fraction. The chemical composition, physical properties and fuel oil quality of fast pyrolysis liquids have widely been developed and described by Oasmaa et al. in many articles [29, 33-36].

\subsection{Efficacy of Wood Vinegar as Pesticide}

A careful literature search on the efficacy of wood vinegar used as a pesticide indicated that only a limited number of scientific publications are available and in many cases the scientific evidence for the marketed products is weak. However, wood vinegar has been widely used as pesticide based on old traditions and knowledge of users and local producers [37].

\subsubsection{Wood Preservative}

Many control technologies has been developed to inhibit fungi that cause discoloration on wood material. Velmurugan and co-authors [38, 39] have published scientific evidence that wood vinegar made from bamboo and broad leaved trees were effective against sapstaining fungi at minimum concentrations (0.10-1.0\%). Results revealed that compounds of Chikusaku-eki and Mokusaku-eki markedly inhibited fungal growth but the exact mode of action of active compounds need to be studied further. Chikusaku-eki and Mokusaku-eki have been reported to possess both antifungal and antioxidant properties as well as potential to be used as natural preservative in wood industries. Extracts are easily available, inexpensive and believed to be non-toxic to the environment. The same products have been used as disinfection, antibacterial and deodorization materials in agriculture and horticulture [40]. However, Chikusaku-eki is mainly used as an ointment for the treatment of scabies, eczema, atopic dermatitis and other skin diseases [41]. Wood tar also has potential as a wood preservative alone or as a component of preservatives [42]. Nakai and co-workers [43] reported that pyrolysis of wood and wood-based wastes is considered to be one of the promising methods of supplying charcoal as solid material and liquids containing a number of valuable chemicals. They attested that some of pyrolysis chemicals may have importance in developing new wood preservatives against fungal degradation.

\subsubsection{Fungicide}

Many publications cite that pyrolysis liquids may be effective fungicides in agricultural applications. The wood vinegars produced from biomasses such as inner coconut shells, bamboo and Eucalyptus wood effectively controlled fungal growth. The antifungal efficiency of wood vinegars was reported to be strongly dependent on their phenolic compounds contents [44]. Importance of phenolic components of vinegar pyrolysed from wood chips has also been reported by Inoue et al. [45].

Preliminary results of a laboratory experiment in Finland indicated that birch tar oil may effectively control growth of potato late blight fungi (Phytophthora infestans) [46]. Furthermore, Jung [47] demonstrated that pyroligneous acid exhibited antifungal activity against some plant pathogens. He also concluded that the acid can substitute a synthetic fungicide and thereby reduce the use of agrochemicals for the control of Alternaria blotch of apple.

\subsubsection{Repellent and Insecticide}

Wood vinegar has been widely used to repel insects from plants and households in Thailand [37] and it is easy to find pyroligneous products marketed on the Internet as an insect repellent. Efficacy of wood vinegar as an insect repellent has not been widely studied or published and thus the scientific evidence is minimal. However, Strong [48] in 1973 reported good results when wheat seed were treated with hardwood tar oil to repel birds, rodents and insects. Hardwood oil was also found to be toxic to all the tested insects. Very similar effects were found when pyroligneous acid was used for controlling insects from sweet corn plots [49]. Wood tars pyrolysed from alder, larch and birch were effective repellents for control of the vole (Clethrionomys rufocanus bedfordiae) in an experiment in Japan [50]. In addition, scientific evidence reported in Finland demonstrated that birch tar oil effectively repelled slugs (Arion lusitanicus) and snails (Aranta arbustorum) [51].

The potential of botanical oils for insect control is well known [52] and botanical insecticides have become increasingly utilized especially in developing countries [15]. Wood vinegar exhibited high termiticidal activities against the Japanese termite Reticulitermes speratus [53] and the authors concluded that an ortho substituent of phenol played an important role in termiticidal activity. Preliminary investigation in Greece showed that one spray application with birch tar oil $(1 \% \mathrm{v} / \mathrm{v}$ aq solution) killed $95 \%$ of aphids (Myzus persicae) on egg plant in a greenhouse experiment. The results of a project [54] in Finland revealed that the birch tar oil may repel egg laying psyllids (Trioza apicalis) but not flies (Delia floralis). Beetles and mites could not be controlled with the oil and it was also non-toxic to predatory mites (Amblysius). Information on wood vinegar application with husbandries suggests repellence of flies, tick and fleas and killing of external parasites [13].

\subsubsection{Wood Vinegar as Herbicide and Plant Growth En- hancer}

Essential oils are known to be effective herbicides [55]. Similarly birch tar oil has shown a herbicidal effect on numerous species of weeds [56]. A preliminary field experiment indicated that pyrolysis liquids made of birch wood can be used for the control of broad leaved weeds [57]. However, there is a lack of scientific evidence to prove the efficacy of vinegar or wood vinegar as herbicide and as such highlights that more research is needed to justify all the claims found via a Web search, i.e. wood vinegar at high concentrations can kill plant cells and low doses may stimulate plant growth.

Field experiments conducted in China have shown that wood vinegar, made from biomass residues, can be used as a foliar fertilizer improving the yield and quality of celery [58]. A mixture of charcoal (biochar) and pyroligneous acid has also shown to enhance soil fertility and the growth of bedding plants [59]. Bamboo vinegar is known to simulate plant growth depending on the pyrolysis temperature [60]. Treatments with bamboo vinegar have also demonstrated an increase in vegetable growth [61]. Other studies have concluded that wood vinegar in organic farming can have a vari- 
ety of applications, including pest control, improving soil fertility, and plant growth promoter or inhibitor. A substantial number of claims have been presented in the form of commercial advertisements, which indicates that more research is urgently needed to improve the scientific basis of the use of wood vinegar in agriculture.

\subsubsection{Wood Vinegar as Feed-Stuff}

It has been suggested that wood vinegar can improve the performance of weanling pigs by improving the nutrient digestibility and reducing harmful intestinal coliforms. Moreover, the performance of pigs fed with wood vinegar was found to be better than those fed with organic acid [62]. Feeding of calves can be activated with charcoal containing wood vinegar. The vinegar liquid called Nekka-Rich showed antiprotozoan activity against Cryptospiridosis parvum oocysts. Calves that were fed milk enriched with Nekka-Rich showed recovery from diarrhea $1 \mathrm{~d}$ after the start of treatment [63]. Mixture of charcoal and wood vinegar was proved to be useful as an aqua feed [64] as well as a useful component in chicken feed [65].

\subsection{Toxicology of Pyrolysis Liquids}

Coal tar has been used for dermatological conditions for more that 2000 years, but also many publications refer to the use of wood tar. Tar ointments have been used in the treatment of psoriasis, scabies, sarcoidosis and dermatitis [66]. Many kinds of raw materials (coal, wood, forestry and agricultural wastes) have been used for tar making and thus, quality and composition of pyrolysis liquids used in toxicological tests has been variable. Carcinogenicity of medicinal ointments containing crude oil, petroleum products, coal tar or wood tar has been studied since 1963 and the health risks associated have been reported in several documents $[67,68]$. Occupational studies have demonstrated the carcinogenic effects of tar, however, epidemiologic studies do not confirm similar outcomes when used topically [66]. In most of the reports demonstrating negative impacts of tars the active ingredient has been coal tar [69]. Due to individual manufacturing techniques, tars differ in chemical composition and as a result, the toxicological studies are divergent [70].

Evidence of wood vinegar toxicity is lacking because it has not been as widely studied as tar products. However, Kimura and co-workers [41] have reported that one of the most widely used wood vinegar Chikusaku-eki did not act as tumor promoter. Thus, chikusaku-eki was not carcinogenic/co-carcinogenic in the in vitro cell transformation assay after being diluted more than 104-fold with water.

The information found does not fully support the toxicological risk analysis of biopesticides made of wood vinegar because most of the published information is based on data collected from experiments where tar (coal and wood based) products have been used to smooth skin intentionally. The same kind of treatments have seldom been carried out with wood vinegar and only rarely with synthetic pesticides. Thus also comparison of wood vinegar toxicity to pesticide toxicity is vague. Toxicological assessment of wood vinegar should be performed specifically for every plant species, taking account the impact of pyrolysis technique on the chemical composition of the liquid.

\subsection{Ecotoxicology}

Hagner et al. [71] concluded that a birch tar oil (a mixture of wood vinegar and birch tar) showed no consistent, direct negative effects on enchytraeid worms, nematodes or soil microbial biomass when used at concentrations between 500-1360 L ha ${ }^{-1}$. Instead, $100 \%$ birch tar oil (500-1360 L $\mathrm{ha}^{-1}$ ) showed a positive effect on microbial activity immediately after application, suggesting that readily utilized substances in the oil were rapidly consumed by microbes. Furthermore, the high LC50 value for the earthworm A. caliginosa indicated that the oil was practically non-toxic to earthworms.

The influence of charcoal and smoke condensates, i.e. pyroligneous acid (PA), on microbial activity in a highly weathered Amazonian upland soil was assessed via measurements of basal respiration (BR), substrate-induced respiration (SIR), and exponential population increase after substrate addition. It was observed that BR, microbial biomass, population growth and the microbe's efficiency increased linearly and significantly with increasing charcoal concentrations (50, 100 and $150 \mathrm{~g} \mathrm{~kg}^{-1}$ soil). Application of PA caused a sharp increase in all parameters. Furthermore, it was concluded that the condensates from smoke contain easily degradable substances and only small amounts of inhibitory agents, which could be utilized by the microbes for their metabolism [72].

It has been found that aquatic organisms appear to be variably responsive to birch tar oil but the oil is much less toxic to most aquatic organisms than, for example, Malathion or Glyphosate. Hagner et al. [73] concluded that a wide range of aquatic organisms are, to some extent, sensitive to the birch tar oil but it does not pose a severe hazard to aquatic biota. Similarly, plant essential oils have been demonstrated to be environmentally friendly.

\subsection{Wood Vinegar Market}

Pyrolysis liquid from fast pyrolysis is a feasible alternative in replacing fossil fuels in European pulp and paper industry $[74,75]$. The European pulp and paper industry has a potential to build up to 50 pyrolyzers integrated to fluidised bed boilers. In the short-term, pyrolysis oil market is in fuel oil and natural gas replacement in lime kilns and boilers, while long-term RTD is focused on transportation fuels.

The only commercial application for fast pyrolysis is still, however, the Red Arrow Products Company plants producing food flavourings, the capacity being around $1 \mathrm{th}^{-1}$ [76]. Integrated energy and chemical production plants are now recognised as having considerable potential for maximising economic viability of the fast pyrolysis plants.

In Japan, the biochar market is developing very fast and may boost the production and use of wood vinegar in agriculture. Respectively, plans to develop an eco town concept will act as a driving force stimulating the use of carbonization as an element of environmental technologies.

The global market value for pesticides was estimated in the year 2000 at 32 billion US\$, with the share of developing countries around 3 billion US\$ [77]. Biological control products have $2-3 \%$ of the world-wide annual turnover of plant protection products [78]. The market of biopesticides 
and biorationals began rapidly increase in the USA by the end of 1999, when EcoSMART Technologies registered over a dozen products [14]. The biorationals data base [79] does not include wood vinegar which may indicate that in many countries the commercialization of botanicals has been focused on essential oils more than on pyrolysis liquids.

In Asia, the wood vinegar market is developing differently. Currently, 189 wood vinegar products have been listed on a commercial home page of which 128 come from China. The wood vinegar based pesticide market is very progressive in Japan and in numerous other Asian countries such as Thailand, Cambodia, and China.

The registration procedure for pesticides differs between countries and as a consequence, pyrolysis liquids have been listed differently. In the USA, vinegar has been listed as a minimum risk pesticide but not wood vinegar. Pine tar oil has been registered for pesticide use in the USA, Australia, New Zealand, Hungary, and Canada, where as tar acid oil is only registered in Australia, India, New Zealand and the United Kingdom. Juniper tar has been listed for use only in New Zealand. In Europe, the wood vinegar market is not comparable to the Asian market.

\section{CONCLUSIONS AND FUTURE PERSPECTIVES}

\subsection{Supporting Factors for the Use of Wood Vinegar}

At present, many driving factors support the development of biological plant protection technologies and use of wood vinegar as a pesticide. Environmental concern related to widespread use of synthetic pesticides is one of the supporting factors, as well as the global policy to diversify the use of organic waste as biofuel and sources of green chemicals.

Pyrolysis technology may offer a "greener" solution to produce energy and chemicals using local resources: plant material, labour and solar energy absorbed by plant cells the factory of green chemicals. Both FAO and WHO have strengthened the discussion on the global need to minimize reliance on fossil fuels as well as the need to improve food and feed production based on locally available resources. According to the new EU regulation, products and substances of plant origin are eligible for authorisation as plant protection products in organic farming [80].

In Europe, the concept of the KBBE launched by the EU as a large scale change of economy may challenge the fossil fuel economy in the long run. Wood vinegar production and the development of botanical based IPM technologies could be one direction for KBBE development if the innovative development of biological control technologies can be economically worthwhile to all kinds of pesticide producers. One critical element in the use of botanicals will be the availability of plant biomass and the quality of the supply chains logistics [15]. Renewable wood material and biological wastes are available in many parts of the world [11] and a large wood biomass supply chain could support pyrolysis firms, for example, in northern Europe [81].

\subsection{Challenges}

Our conclusions on the utilization of wood vinegar as a future pesticide are indeed similar to those published already in the year 2000 by Isman [14] and we can fully concur with the suggestions listed in the final report of the REBECA project [82].

In Europe, the commercialization of biological control agents including wood vinegar is practically impossible for small to medium enterprises (SME) if the registration procedure, developed for the registration of synthetic chemicals, cannot be modified as suggested in the REBECA report [82]. However, aims to multiply the use of "alternative control techniques" as described in the newly accepted EU directive [2] and the regulation [3] may be difficult to achieve in practice. At worst, a considerable loss of time and money from SMEs and research institutions will occur and the final results will be a list of innovative biorational publications coupled with bankrupt SMEs looking to invest in other business areas.

Outside of Europe the development of biorationals will be somewhat different. In the USA, commercialization of essential oils has proved that it might be realistic to reach for biocontrol market leadership - as some companies have already targeted $[14,15]$. Similarly, the wood vinegar market will develop fast in Japan, China, India, Thailand, and all the countries having long tradition on the use of slow pyrolysis techniques for charcoal making.

Based on the literature review it can be concluded that the chemical composition of wood vinegar products is not well known and the mode of action as a pesticide is unclear. This comes even though several studies highlight it as an efficacious product that has low ecotoxicological impacts. Furthermore, none of the presently used synthetic pesticides has such a long trouble-free history in agricultural practices as wood vinegar in many of the Asian countries where it is utilized. It seems obvious that the replacement of synthetic pesticides with biorationals will be a slow process worldwide, except perhaps in developing countries where small scale farmers have almost nothing else to use or to replace it with. In Europe, wood vinegar could be one of "the substances which may be of value for plant protection" as was described in the new EU regulation [3]. However, replacement of synthetic pesticides with wood vinegar is possible only if barriers to restrain the commercialization of plant based products will be lower [83] and the registration system of biological control agents will follow the suggestions outlined in the REBECA project [78, 82].

\section{ACKNOWLEDGEMENTS}

The authors wish to thank Sirima Sornsuwan, Rauno Laitalainen and Taisto Jaakola for helping to get information from Mozambique, Thailand and other Asian countries. Financial support was provided by Tekes, the Finnish Funding Agency for Technology and Innovation.

\section{REFERENCES}

[1] Sustainable use of pesticides. European Commission, Environment Chemicals, Plant protection Products 2009 [updated 2009 June 16; cited 2009 Oct 19]. Available from: http://ec.europa.eu/environment/ppps/home.htm

[2] The European Parliament and the Council. Establishing a framework for community action to achieve the sustainable use of pesticides. Directive of the European Parliament and the Council 2009.

[3] The European Parliament and the Council. Regulation of the European Parliament and the Council concerning the placing of plant 
protection products on the market and repealing Council Directives 79/117/EEC and 91/414/EEC 2009.

[4] FAO Council. Report of the twenty-first session of the committee on agriculture (COAG), Rome, April 22-25, 2009.

[5] GoodPlanet. Info. Food and Agriculture. When FAO foresees an organic future [cited 2009 Oct 13]. Available from: http://www.goodplanet.info/goodplanet/index.php/eng/Contenu/Poi nts-de-vues/When-FAO-forsees-an-organic-future/(theme)/3105

[6] EcoSMART Technologies. Finally safe and effective insecticide for the green market [home page on the Internet] [cited 2009 Oct 10]. Available from: http://www.ecosmart.com/commercial/default.asp

[7] European Commission. Towards a European knowledge-based bioeconomy. Workshop conclusion on the use of plant biotechnology for the production of industrial bio-based products. York University 2004 [cited 2009 Oct 19]. Available from: http://ec.europa.eu/research/agriculture/pdf/towards_know-based_bioeconomy.pdf

[8] Laemsak N. Wood Vinegar, Slide Presentation, Wood \& Pulp Research Program Coordinating Office, TRF Faculty of Forestry, Kasetsart University 2007; [cited 2009 Oct 19]. Available from: http://www.rdi.ku.ac.th/news_announce/kurdi/Year_48/15/Woodvi negar.pdf

[9] New energy and fuel. Pyrolysis goes commercial scale [home page on the Internet] 2009; [updated 2009 March 31; cited 2009 Oct 15]. Available from: http://newenergyandfuel.com/http:/newenergyandfuel/com/2009/03/31/pyrolysis-goes-commercial-scale/

[10] Schmidt BM, Ribnicky DM, Lipsky PE, Raskin I. Revisiting the ancient concept of botanical therapeutics. Nat Chem Biol 2007; 3: 360-6.

[11] Shuhua G. International Conference on Bioenergy Utilization and Environment Protection, 6th LAMNET Project Workshop, Dalian, China, September 24-26, 2003. Conference Proceedings. 2003; [cited Oct 2009]. Available from: http://www.bioenergy-lamnet.org/publications/source/LamnetPublications/2-GuShuhua.pdf

[12] Zhu X, Jiang H, Guo Q, Zhu Q. Biomass Pyrolysis and its Potential for China. International Conference on Bioenergy Utilization and Environment Protection - 6th LAMNET Project Workshop, Dalian, China, September 24-26, 2003. Workshop Proceedings 1. 2003; [cited 2009 Oct 19]. Available from: http://www.bioenergylamnet.org/publications/source/chi2/Session3-ZhuXifeng-

LAMNET-WS-Dalian-0309.pdf

[13] Appropriate Technology Association. Wood vinegar production and utilization. First Publication 2006.

[14] Isman MB. Plant essential oils for pest and disease management. Crop Prot 2000; 19: 603-8.

[15] Isman MB. Botanical insecticides, deterrents, and repellents in modern agriculture and an increasingly regulated world. Annu Rev Entomol 2006; 51: 45-66.

[16] Grünberg JM, Graetsch H, Baumer U, Koller J. Untersuchung der mittelpaläolithischen "Harzreste" von Königsaue, Ldkr. Aschersleben-Staßfurt. Jahresschrift für Mitteldeutsche Vorgeschichte 1999; 81: 7-38.

[17] Sauter F, Graf A, Hametner C, Fröhlich J. Studies in organic archaeometry III. Prehistoric adhesives: alternatives to birch bark pitch could be ruled out. ARKIVOC 2001; 21-4.

[18] Mazza PPA, Martini F, Sala B, et al. A new Palaeolithic discovery: tar-hafted stone tools in a European Mid-Pleistocene bone-bearing bed. J Archaeol Sci 2006; 33(9): 1310-8.

[19] Sirelius UT. Suomen kansanomaista kulttuuria II. Helsinki, Kustanngsosakyhtiö Otava, Finnish 1921; 50-1.

[20] Aveling EM, Heron C. Chewing tar in the early Holocene: an archaeological and ethnographic evaluation. Antiquity 1999; 73: 57984.

[21] Pesonen P. Tervanpolton juurilla - koivutervan käyttö saviastian korjauksessa kivikaudella. Tekniikan Waiheita. Finnish 1994; 1: 47.

[22] Bonfield KM, Heron C, Nemcek N. In: Brzeziński W, Piotrowski W, Eds. The chemical characterization of wood tars in prehistoric Europe: a case study from the Neolithic of Southern Germany. Proceedings of the First International Symposium on Wood Tar and Pitch, Warszawa 1997.

[23] Lucquin A, March RJ, Cassen S. Analysis of adhering organic residues of two "coupes-a-socles" from the Neolithic funerary site "La Hougue Bie" in Jersey: evidences of birch bark tar utilisation. J Archaeol Sci 2007; 34: 704-10.
[24] Sjöström E. Wood chemistry, fundamentals and applications, 2nd ed. San Diego: Academic Press 1993; pp. 234-5.

[25] Goldstein IS. Organic chemicals from biomass, Florida: CRC Press, Inc., 1983; pp. 64-95.

[26] Fengel D, Wegener G. Wood, chemistry, ultrastructure, reactions. Berlin-New York: Walter de Gruyter 1984; pp. 527-9.

[27] Antal MJ Jr. The art, science, and technology of charcoal production, Ind Eng Chem Res 2003; 1619-40.

[28] Scott DS, Piskorz J. The flash pyrolysis of aspen-poplar wood. Can J Chem Eng 1982; 60: 666-74.

[29] Oasmaa A. Fuel oil quality properties of wood-based pyrolysis liquids. Academic dissertation, Research Report Series No. 99, Department of Chemistry, University of Jyväskylä, Jyväskylä, 2003; 32 p + app. 251 p.

[30] Bridgwater AV, Czernik S, Diebold J, et al. Fast pyrolysis of biomass: A Handbook. CPL Press: Newbury, UK 1999; p. 188.

[31] Bridgwater AV, Ed. Fast pyrolysis of biomass: A Handbook. CPL Press: Newbury, UK 2002; vol. 2: p. 424.

[32] Mokusaku wood vinegar pyroligneous acid, Product overview [cited 2009 Oct 19]. Available from http://www.doishouten.co.jp/english/page_english1/e_product.html

[33] Oasmaa A, Meier D. Characterisation, analysis, norms \& standards. In: Bridgwater AV. Ed. Fast Pyrolysis of Biomass: A Handbook., CPL Press: Newbury, UK 2005; Vol. 3: pp. 19-60.

[34] Oasmaa A, Peacocke C. A guide to physical property characterisation of biomass-derived fast pyrolysis liquids. Technical Research Centre of Finland, VTT Publications 450, Espoo, 2001; 65 p. + app. 34 p.

[35] Sipilä K, Kuoppala E, Fagernäs L, Oasmaa A. Characterization of biomass-based flash pyrolysis oils. Biomass Bioenergy 1998; 14(2): 103-13.

[36] Fagernäs L. Chemical and physical characterisation of biomassbased pyrolysis oils. Literature review. VTT Research Notes 1706, Espoo, 1995; 14(2): 103-13.

[37] Sirima Sornsuwan, Thailand, personal communication.

[38] Velmurugan N, Chun SS, Han SS, Lee YS. Characterization of chikusaku-eki and mokusaku-eki and its inhibitory effect on sapstaining fungal growth in laboratory scale. Int J Environ Sci Technol 2009; 6(1): 13-22.

[39] Velmurugan N, Han SS, Lee YS. Antifungal activity of neutralized wood vinegar with water extracts of Pinus densiflora and Quercus serrata saw dusts. Int J Environ Res 2009; 3(2): 167-76.

[40] Imamura E. Anti-allergy composition comprising wood vinegar or bamboo vinegar distilled solution. United States patent US 7214393. August 2007.

[41] Kimura Y, Suto S, Tatsuka M. Evaluation of carcinogenic/cocarcinogenic activity of chikusaku-eki a bamboo charcoal byproduct used as folk remedy in BALAB/c 3T3 cells. Biol Pharm Bull 2002; 25(8): 1026-9.

[42] Mazela B. Fungicidal value of wood tar from pyrolysis of treated wood. Waste Manage 2007; 27: 461-5.

[43] Nakai T, Kartal N, Hata T, Imamura Y. Chemical characterization of pyrolysis liquids of wood-based composites and evaluation of their bio-efficiency. Build Environ 2007; 42: 1236-41.

[44] Baimark Y, Niamsaa N. Study on wood vinegars for use as coagulating and antifungal agents on the production of natural rubber sheets. Biomass Bioenergy 2009; 33: 994-8.

[45] Inoue S, Hata T, Imamura Y, Meier D. Components and anti-fungal efficiency of wood-vinegar-liquor prepped under different carbonization conditions. Wood Res 2000; 87: 34-6.

[46] Tiilikkala K, Hannukkala A, Lipponen K, Tahvonen R, Lalli I. In Tiilikkala K, Segerstedt M, Eds. Antifungal and anti-microbial effect of birch tar oil (BTO). Koivutisle - kasvinsuojelun uusi innovaatio 2009; 143: 1-129 [cited 2009 Oct 20]. Available from: http://www.mtt.fi/met/pdf/met143.pdf

[47] Jung K-H. Growth inhibition effect of pyroligneous acid on pathogenic fungus, Alternaria mali, the agent of Alternaria blotch of apple. Biotechnol Bioprocess Eng 2007; 12(3): 318-22.

[48] Strong RG. Protection of wheat seed with hardwood tar oil in a Dust Formulation. Environ Entomol 1973; 2(6): 1126-7.

[49] Pangnakorn U. Utilization of wood vinegar by-product from Iwate kiln for organic agricultural system. Technology and Innovation for Sustainable Development Conference (TISD2008) Faculty of Engineering, Khon Kaen University, Thailand, January 28-29, 2009. 
[50] Orihashi K, Kojima Y, Terazawa M. Deterrent effect of rosin and wood tar against barking by the gray-sided vole (Clethrionomys rufocanus bedfordiae). J Forest Res 2001; 6: 191-6.

[51] Lindqvist I, Lindqvist B, Tiilikkala K, et al. Birch tar oil is an effective mollusc repellent: field and laboratory experiments using Arianta arbustorum (Gastropoda: Helicidae) and Arion lusitanicus (Gastropoda: Arionidae). Agric Food Sci 2010; 19: 1-12.

[52] Regnault-Roger C. The potential of botanical essential oils for insect pest control. Integr Pest Manage Rev 1997; 2: 25-34.

[53] Yatagai M, Nishimoto M, Hori K, Ohira T, Shibata A. Termiticidal activity of wood vinegar, its components and homologues. J Wood Sci 2002; 48(4): 338-42.

[54] Lindqvist I, Lindqvist B, Tuovinen, et al. In: Tiilikkala K, Segerstedt M, Eds. The potential of botanical birch tar oil for insect pest control. Koivutisle - kasvinsuojelun uusi innovaatio 2009; 143: 1-129 [cited 2009 Oct 20]. Available from: http://www.mtt.fi/met/pdf/met143.pdf

[55] Tworkoski T. Herbicide effects of essential oils. Weed Sci 2002; 50: 425-31.

[56] Salonen J, Tiilikkala K, Ruuttunen P, Lindqvist I, Lindqvist B. Birch Tar Oil: A Potential Herbicide from the Forests of Finland. In: Abstracts of the 5th International Weed Science Congress. Weeds local problems/global challenge. Vancouver, British Columbia, Canada: IWSS, June 23-27, 2008.

[57] Ruuttunen P. Evaluation of birch oil distillate for weed control in potato. MTT Agrifood Research Trial report, Herbicides 2007; 110 [cited 2009 Oct 20]. Available from: https://portal.mtt.fi/portal/page/portal/mtt_en/mtt/facilities/testing PPs/trialresults/2007/herbicides_broadleaved_crops/07HerbP2.pdf

[58] Wei QY, Liu GQ, Wei XM, Ma XXX, Dong L, Dong RJ. Influence of wood vinegar as leaves fertilizer on yield and quality of celery. $\mathrm{J}$ China Agric University 2009; 14(1): 89-92 [cited 2009 Oct 20]. Available from: http://www.ilib2.com/A-ISSN 10074333(2009)01-0089-04.html

[59] Kadota M, Niimi Y. Effects of charcoal with pyroligeneous acid and barnyard manure on bedding plants. Sci Hortic 2004; 101: 32732.

[60] Mu J, Uehara T, Furuno T. Effect of bamboo vinegar on regulation of germination and radicle growth of seed plants II: composition of moso bamboo vinegar at different collection temperature and its effects. J Wood Sci 2004; 50(5): 470-6.

[61] Mu J, Yu Z, Wu W, Wu Q. Preliminary study of application effect of bamboo vinegar on vegetable growth. Forest Stud Chin 2006; 8(3): 43-7.

[62] Choi JH, Shinde PL, Kwon IK, Song YH, Chae BJ. Effect of wood vinegar on the performance, nutrient digestibility and intestinal microflora in weanling pigs. Asian Aust J Anim Sci 2009; 22(2): 26774.

[63] Watarai S, Koiwa M. Feeding activated charcoal from bark containing wood vinegar liquid (Nekka-Rich) is effective as treatment for Cryptosporidiosis in calves. J Dairy Sci 2008; 91: 1458-63.

[64] Yoo JH, Ji SC, Jeong GS. Effect of dietary charcoal and wood vinegar mixture (CV82) on body composition of Olive Flounder Paralichthys alivaceus. J World Aquac Soc 2007; 36(2): 203-8.

[65] Samanya M, Yamauchi K. Morphological changes of the intestinal villi chickens fed the dietary charcoal powder including wood vinegar compounds. J Poult Sci 2001; 38: 289-301.

[66] Paghdal KV, PharmD MD, Schwartz MD. Topical tar. Back to the future. J Am Acad Dermatol 2009; 61: 294-302.

[67] Serkovskaya GS. Carcinogenicity of medicinal ointments containing crude oil, petroleum products, coal tar, or wood tar. Chem Technol Fuels Oils 1997; 33(6): 368-72.
[68] Schoket B, Horkay I, Kosa A, et al. Formation of DNA adducts in the skin of psoriasis patients, in human skin, in organ culture and in mouse skin and lung following topical application of coal-tar and juniper tar. J Invest Dermatol 1990; 94: 241-6.

[69] Mukhtar H, Link CM, Cherniack E, Kushner DM, Bickers DR. Effect of topical application of defined constituents of coal tar on skin and liver aryl hydrocarbon hydroxylase and 7-ethoxycoumarin deethylase activities. Toxicol Appl Pharmacol 1982; 64(3): 541-9.

[70] Schmid MH, Korting HC. Coal tar, pine tar and sulfonated shale oil preparations: comparative activity, efficacy and safety. Dermatology 1996; 193: 1-5.

[71] Hagner M, Pasanen T, Lindqvist B, et al. Effects of birch tar oils on soil organisms and plants. Agric Food Sci 2010; 19: 13-23.

[72] Steiner C, Das KC, Garcia M, Forster B, Zech W. Charcoal and smoke extract stimulate the soil microbial community in a highly weathered xanthic Ferralsol. Pedobiologia 2008; 51(5-6): 359-66.

[73] Hagner M, Penttinen O-P, Pasanen T, Tiilikkala K, Setälä H. Acute toxicity of birch tar oil on aquatic organisms. Agric Food Sci 2010; 19: 24-33.

[74] Sipilä E, Vasara P, Solantausta Y, Sipilä K. Feasibility and market potential of pyrolysis oils in the European pulp \& paper industry. Proc. 15th European Biomass Conference From Research to Market Deployment, Berlin, Germany, May 7-11, 2007.

[75] Bradley D. European market study for bio-oil (pyrolysis oil), IEA Bioenergy Task 40 - Biotrade, Dec 15, 2006.

[76] Bridgwater AV, Peacocke GVC. Fast pyrolysis processes for biomass. Renew Sustain Energy Rev 2000; 4: 1-73.

[77] FAO/WHO. Amount of poor-quality pesticides sold in developing countries alarming high. Food and Agriculture organization of the United Nations, Press Release 01/05 [cited 2009 Oct 20]. Available from:

http://www.fao.org/WAICENT/OIS/PRESS_NE/PRESSENG/2001 /pren0105.htm

[78] Ehlers R-U. In: Gisi U, Gullino ML, Eds. Rebeca -EU-Policy support action to review regulation of biological control agents. Recent Dev Manage Plant Dis 2009; 1: 147.

[79] Dufour R. Biorationals: Ecological Pest Management Database. National sustainable Agriculture Information service [home page on the Interner] [cited 2009 Oct 13]. Available from: http://attra.ncat.org/attra-pub/biorationals/index.php

[80] Speiser B. In: Mikkelson C, Schluter M, Eds. The new EU regulation for organic food and farming. Crop production and crop inputs. 2009 [home page on the internet] [cited 2009 Oct 14]. Available from: www.ifoam-eu.org

[81] Grinwis R. A successful transition towards a bio-based economy. A study on critical factors from Finnish cases 2008; [cited 2009 Oct 19]. Available from: http://206.132.223.45/upl_documents/Towards $\% 20$ a $\% 20$ biobased $\% 20$ economy $\% 20$-\%20Rianne\%20Grinwis\%20-\%20Internship\%20report.pdf

[82] Ehlers R-U. Regulation of biological control agents. REBECA Project no. SSPE-CT-2005-022709 Final Activity Report 2006 [cited 2009 Oct 21]. Available from: http://www.rebecanet.de/downloads/report/REBECA\%20Final\%20Acivity\%20Repor t\%20v5.pdf

[83] Price NR, Stopes C. Routes and barriers to the further exploitation of strategic research into biorational pesticides at CSL. With specific reference to MAFF projects PI0336, PI0337 and PI338 [cited 2009 Oct 22]. Available from: https://aims.defra.gov.uk/homepage/documents/23.doc

This is an open access article licensed under the terms of the Creative Commons Attribution Non-Commercial License (http://creativecommons.org/licenses/ by-nc/3.0/) which permits unrestricted, non-commercial use, distribution and reproduction in any medium, provided the work is properly cited. 